Abstracta Iranica Abstracta Iranica

Revue bibliographique pour le domaine irano-aryen

Volume 28 | 2007

Comptes rendus des publications de 2005

« Politica e credibilità personale. Un diplomatico francescano tra Tabriz e la Borgogna (1450 circa-1479) ». Quaderni Storici, n.s. 118, aprile 2005, pp. 3-40.

Angelo-Michele Piemontese

\title{
OpenEdition
}

Journals

Édition électronique

URL : http://journals.openedition.org/abstractairanica/17392

DOI : 10.4000/abstractairanica.17392

ISSN : 1961-960X

Éditeur :

CNRS (UMR 7528 Mondes iraniens et indiens), Éditions de l'IFRI

Édition imprimée

Date de publication : 15 mai 2007

ISSN : 0240-8910

Référence électronique

Angelo-Michele Piemontese, « « Politica e credibilità personale. Un diplomatico francescano tra Tabriz e la Borgogna (1450 circa-1479) ». Quaderni Storici, n.s. 118, aprile 2005, pp. 3-40. », Abstracta Iranica [En ligne], Volume 28 | 2007, document 155, mis en ligne le 18 septembre 2007, consulté le 25 septembre 2020. URL : http://journals.openedition.org/abstractairanica/17392 ; DOI : https://doi.org/ 10.4000/abstractairanica.17392

Ce document a été généré automatiquement le 25 septembre 2020.

Tous droits réservés 


\section{« Politica e credibilità personale. Un diplomatico francescano tra Tabriz e la Borgogna (1450 circa-1479) ». Quaderni Storici, n.s. 118, aprile 2005, pp. 3-40.}

\section{Angelo-Michele Piemontese}

L'A., médiéviste et historien de l'Ordre franciscain, éclaire la biographie de Ludovicus Bononiensis, rejeton de la famille Bolonaise des Severi, dont la figure est replacée sur l'échiquier international $\mathrm{du} \mathrm{XV}^{\mathrm{e}}$ siècle. Ludovicus, moine franciscain et patriarche, accomplit de complexes missions diplomatiques (env. 1450-1479), et comme nonce de plusieurs Papes (dont Sixte IV, 1471-1484, lui-même un Franciscain éminent), et comme ambassadeur de Bourgogne auprès de Uzūn Ḥasan Āq-Qoyūnlū. Cf. B. Paviot, Les Ducs de Bourgogne, la croisade et l'Orient (fin XIV'siècle-XVe siècle), Paris, 2003, pp. 158-159, 190-191, 265-270. Ludovicus fait preuve d'une remarquable habileté dans la médiation diplomatique, lorsque l'Iran s'allie aux puissances européennes afin de combattre l'empire ottoman. Entre autres, Uzūn Ḥasan envoie une ambassade à Urbino, duché ami de la Bourgogne et allié de Rome sous Sixte IV : cf. A. M. Piemontese, «L'Ambasciatore del Re di Persia presso Federico da Montefeltro, Ludovicus Bononiensis O.F.M. e il cardinale Bessarione", Miscellanea Bibliothecae Apostolicae Vaticanae XI, Città del Vaticano, 2004, pp. 539-569 [cf. Abs. Ir. 27, 2004, c.r. n ${ }^{\circ 0} 155$ ]. 
INDEX

Thèmes : 4.1. Histoire médiévale

\section{AUTEURS}

ANGELO-MICHELE PIEMONTESE

Rome 